\title{
Uptake, distribution, metabolism, and elimination of styrene in man. A comparison between single exposure and co-exposure with acetone
}

\author{
E WIGAEUS, A LÖF, AND M BYFÄLT NORDQVIST \\ From the Research Department, National Board of Occupational Safety and Health, Solna, Sweden
}

\begin{abstract}
Six male subjects were exposed for two hours during light physical exercise to $2 \cdot 81$ $\mathrm{mmol} / \mathrm{m}^{3}\left(293 \mathrm{mg} / \mathrm{m}^{3}\right)$ of styrene on one occasion and to a mixture of $2.89 \mathrm{mmol} / \mathrm{m}^{3}\left(301 \mathrm{mg} / \mathrm{m}^{3}\right)$ of styrene and $21.3 \mathrm{mmol} / \mathrm{m}^{3}\left(1240 \mathrm{mg} / \mathrm{m}^{3}\right)$ of acetone on another (combination study). About $68 \%$ of the dose (somewhat more than $4 \mathrm{mmol}$ ) of styrene was taken up. The arterial blood concentration of styrene reached a relatively stable level after about 75 minutes of exposure of about 18 and $20 \mu \mathrm{mol} / \mathrm{l}$ after the single and combined exposure, respectively. Calculated values of mean blood clearance were $1.9 \mathrm{l} / \mathrm{min}$ in the styrene study and $1.6 \mathrm{l} / \mathrm{min}$ in the combination study; the half life of styrene in blood was about 40 minutes in both studies. The concentration of non-conjugated styrene glycol increased linearly during exposure and reached about $3 \mu \mathrm{mol} / \mathrm{l}$ at the end of exposure and was eliminated with a half life of about 70 minutes. Styrene-7,8-oxide was detected and quantified in the blood in a complementary study. The half lives for the excretion of mandelic and phenylglyoxylic acid in the urine were about four and nine hours, respectively, in both studies.
\end{abstract}

Styrene is one of the most widely used raw materials in the modern polymer industry and the most extensive and intensive exposure occurs in the reinforced plastics industry. ${ }^{1}$ Laminaters are also often exposed to acetone used as a cleaning agent. ${ }^{2}$

Exposure of experimental animals and man to isopropanol or its keto metabolite acetone has been shown to potentiate the effects of hepatic and renal toxins such as chlorinated hydrocarbons ${ }^{3-9}$ perhaps by increasing their covalent binding to hepatic proteins. ${ }^{111}$ Acetone is largely responsible for the remarkable potentiating ability of isopropanol, ${ }^{12}$ which may be important when considering occupational exposure where exposure to a variety of chemical agents can alter the toxic effects of any one of them.

The mechanism of potentiation of hepatotoxicity has been postulated to be either non-specific membrane changes which render the cell more susceptible to toxic injury ${ }^{4}$ or increased bioactivation of the toxicants to reactive intermediates, ${ }^{4671113-17}$ or both. Other effects on cellular function or metabolism, however, cannot be excluded. ${ }^{6711}$

Received 8 August 1983

Accepted 26 September 1983
The metabolism of styrene takes place mainly in the liver but also occurs in extrahepatic tissues. ${ }^{18-21}$ The biotransformation is stimulated by styrene itself $^{2223}$ and phenobarbital ${ }^{2124}$ and is suppressed by the coadministration of ethanol, toluene, and trichloroethylene. ${ }^{25-27}$ The first step in the major metabolic pathway is the formation of styrene-7, 8 -oxide (SO), ${ }^{28} 29$ a reaction preferentially catalysed by the microsomal cytochrome P-450 system. It is now generally accepted that the toxicity of styrene may be mainly ascribed to its biotransformation to the more reactive compound SO which is known to be mutagenic ${ }^{30-35}$ and capable of covalent binding to macromolecules in vivo (M Byfält Nordgvist et al, in preparation). ${ }^{36} \mathrm{SO}$ is hydrated to styrene glycol (SG) which is catalysed by epoxide hydratase ${ }^{3738}$ with subsequent metabolism to mandelic, phenylglyoxylic, benzoic, and hippuric acids; SO is also conjugated with glutathione (GSH) with urinary elimination of mercapturic acids. ${ }^{21}$ Conjugation of SG with glucuronic acid and styrene metabolism to 1and 2-phenylethanols and to 4-vinylphenol are minor pathways. ${ }^{21}$ In man about $90 \%$ of the styrene uptake is eliminated as mandelic and phenylglyoxylic acids. ${ }^{3940}$

Acetone has been shown to enhance the hepatic 


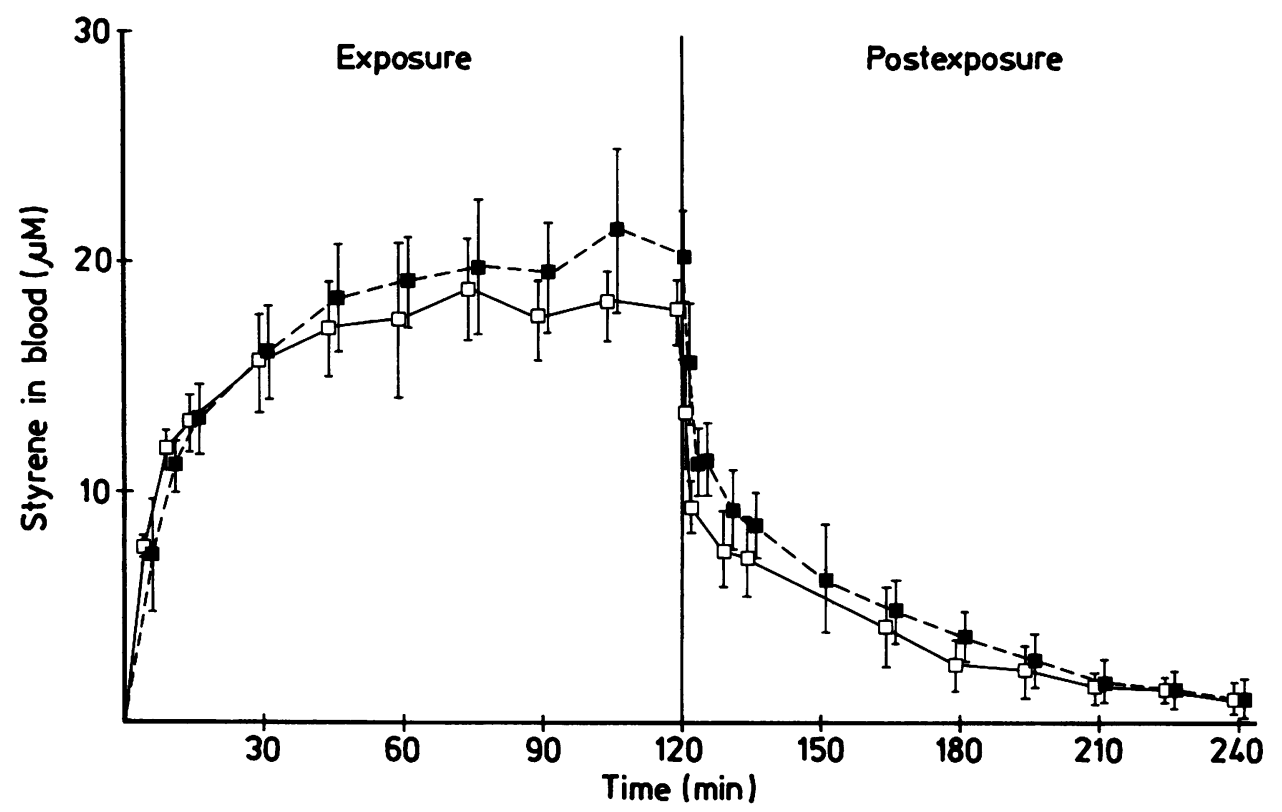

Fig 1 Concentration of styrene in arterial blood for five subjects during and after exposure to $2 \cdot 81$ $\mathrm{mmol} / \mathrm{m}^{3}\left(293 \mathrm{mg} / \mathrm{m}^{3}\right)$ of styrene ( $\square$ ) and to a combination of $2.89 \mathrm{mmol} / \mathrm{m}^{3}\left(301 \mathrm{mg} / \mathrm{m}^{3}\right)$ of styrene and $21.3 \mathrm{mmol} / \mathrm{m}^{3}\left(1240 \mathrm{mg} / \mathrm{m}^{3}\right)$ of acetone (口) for two hours during physical exercise with a work load of $50 \mathrm{~W}$. Mean values $(n=5)$ and standard deviations are shown.

metabolism of various drugs in vitro ${ }^{4-44}$ and in vivo. ${ }^{10174546}$ Significantly reduced hepatic glutathione concentrations and slightly increased hepatic cytochrome $\mathrm{P}-\mathbf{4 5 0}$ levels have been shown in rats after inhalation exposure to acetone alone and to a mixture of acetone and styrene ${ }^{47} \mathrm{~A}$ dose dependent depression of hepatic glutathione level has been observed after inhalation exposure to styrene. ${ }^{48}$ The covalent binding of SO to rat liver macromolecules has been shown to be dependent on the glutathione content of the liver. ${ }^{36}$

The purpose of this study was to investigate if the uptake, distribution, metabolism, or elimination, or a combination of these, of styrene in man after an acute exposure was modified by simultaneous exposure to acetone at the recommended Swedish short term exposure limit concentrations.

\section{Subjects and methods}

The volunteers were six healthy men with an average age of 26 (range 23-34), an average weight of $69 \mathrm{~kg}$ (range 60-80) and an average height of 177 cm (range 172-180). They had no occupational exposure to solvents and none had suffered from any disease having a detrimental effect on the function of the respiratory and circulatory systems.
The subjects were exposed in pairs in an exposure chamber for two hours to 2.81 (SD 0.03 ) $\mathrm{mmol} / \mathrm{m}^{3}$ $\left(293 \mathrm{mg} / \mathrm{m}^{3}\right)$ of styrene on one occasion and to a mixture of $2.89($ SD 0.04$) \mathrm{mmol} / \mathrm{m}^{3}\left(301 \mathrm{mg} / \mathrm{m}^{3}\right)$ of styrene and $21.3(\mathrm{SD} 0.2) \mathrm{mmol} / \mathrm{m}^{3}\left(1240 \mathrm{mg} / \mathrm{m}^{3}\right)$ of acetone on another (combination study). The two exposures were at least one month apart. The recommended Swedish short term exposure limit value is $2.88 \mathrm{mmol} / \mathrm{m}^{3}\left(300 \mathrm{mg} / \mathrm{m}^{3}\right)$ for styrene and $20.7 \mathrm{mmol} / \mathrm{m}^{3}\left(1200 \mathrm{mg} / \mathrm{m}^{3}\right)$ for acetone. The exposures were performed during light physical exercise (work load of $50 \mathrm{~W}$ ) on a bicycle ergometer.

The uptake of styrene was measured using the Douglas bag technique. Unchanged styrene and the styrene metabolites styrene glycol (SG) and styrene oxide (SO) were analysed by gas chromatography in arterial blood sampled during and after exposure (sampling times are shown in fig 1). The styrene concentration in subcutaneous adipose tissue was determined by gas chromatography in biopsy specimens taken 30 and 90 minutes after exposure. The concentrations of mandelic and phenylglyoxylic acid (MA and PGA) in the urine, in samples taken up to about 25 hours after exposure, were analysed by isotachophoresis. For details of the exposure conditions and the analytical methods used in the deter- 
Table 1 Experimental results from two hours of exposure to about $2 \cdot 81 \mathrm{mmol} / \mathrm{m}^{3}\left(293 \mathrm{mg} / \mathrm{m}^{3}\right)$ of styrene (St) and $2 \cdot 89$ $\mathrm{mmol} / \mathrm{m}^{3}\left(301 \mathrm{mg} / \mathrm{m}^{3}\right)$ of styrene and $21.3 \mathrm{mmol} / \mathrm{m}^{3}\left(1240 \mathrm{mg} / \mathrm{m}^{3}\right)$ of acetone $(\mathrm{St}+\mathrm{Ac})$ in combination during physical exercise with a work load of $50 \mathrm{~W}$. The pulmonary ventilation (VE), the amount of styrene given and taken up, and the relative uptake of styrene are given during each 30 minute period. The arterial blood concentration of styrene and styrene glycol are given at the end of each 30 minute period. Mean values and standard errors of means are given

\begin{tabular}{|c|c|c|c|c|c|c|}
\hline$\underset{(\text { min })}{\text { Time period }}$ & $\begin{array}{l}V E B T P S^{*} \\
(l / \min ) \\
(n=6)\end{array}$ & $\begin{array}{l}\text { Amount given } \\
(m m o l) \\
(n=6)\end{array}$ & $\begin{array}{l}\text { Uptake } \\
(m \operatorname{mol}) \\
(n=6)\end{array}$ & $\begin{array}{l}\text { Uptake in \% of } \\
\text { given amount } \\
(n=6)\end{array}$ & $\begin{array}{l}\text { Styrene concentration } \\
\text { in arterial blood } \\
(\mu M) \\
(n=5)\end{array}$ & $\begin{array}{l}\text { Styrene glycol } \\
\text { concentration in } \\
\text { arterial }(\mu M) \\
(n=5)\end{array}$ \\
\hline $\begin{array}{c}0-30 \mathrm{St} \\
\mathrm{St}+\mathrm{Ac} \\
30-60 \mathrm{St} \\
\mathrm{St}+\mathrm{Ac} \\
60-90 \mathrm{St} \\
\mathrm{St}+\mathrm{Ac} \\
90-120 \mathrm{St} \\
\mathrm{St}+\mathrm{Ac} \\
0-120 \mathrm{St} \\
\mathrm{St}+\mathrm{Ac}\end{array}$ & $\begin{array}{l}19.6 \pm 1.2 \\
19.0 \pm 2.2 \\
20.8 \pm 0.8 \\
19.2 \pm 1.5 \\
20.3 \pm 0.9 \\
19.1 \pm 1.7 \\
21.2 \pm 1.3 \\
20.2 \pm 1.5 \\
20.5 \pm 0.9 \\
19.4 \pm 1.7\end{array}$ & $\begin{array}{l}1.54 \pm 0.09 \\
1.53 \pm 0.19 \\
1.66 \pm 0.07 \\
1.57 \pm 0.13 \\
1.62 \pm 0.08 \\
1.62 \pm 0.15 \\
1.68 \pm 0.11 \\
1.71 \pm 0.13 \\
6.50 \pm 0.30 \\
6.42 \pm 0.60\end{array}$ & $\begin{array}{l}1.09 \pm 0.05 \\
1.03 \pm 0.08 \\
1 \cdot 10 \pm 0.03 \\
1.03 \pm 0.05 \\
1.09 \pm 0.06 \\
1.06 \pm 0.07 \\
1.09 \pm 0.06 \\
1 \cdot 10 \pm 0.06 \\
4.38 \pm 0.17 \\
4.22 \pm 0.26\end{array}$ & $\begin{array}{l}71 \cdot 0 \pm 1.6 \\
68.8 \pm 2.7 \\
67 \cdot 1 \pm 2.0 \\
66.2 \pm 2.3 \\
67.2 \pm 2.1 \\
66.1 \pm 2.0 \\
66.7 \pm 2.3 \\
64.9 \pm 1.9 \\
67.7 \pm 1.9 \\
66.6 \pm 2.2\end{array}$ & $\begin{array}{l}15.6 \pm 1.0 \\
16.1 \pm 0.9 \\
17.4 \pm 1.5 \\
19.1 \pm 0.9 \\
17.4 \pm 0.7 \\
19.4 \pm 1.0 \\
17.9 \pm 0.6 \\
20.2 \pm 0.9\end{array}$ & $\begin{array}{l}1.41 \pm 0.28 \\
1.24 \pm 0.21 \\
2.08 \pm 0.43 \\
2.12 \pm 0.31 \\
2.72 \pm 0.47 \\
2.97 \pm 0.79 \\
3.08 \pm 0.56 \\
3.20 \pm 0.67\end{array}$ \\
\hline
\end{tabular}

${ }^{*}$ Temperature of $37^{\circ} \mathrm{C}$, ambient pressure, saturated with water.

mination of styrene and its metabolites the reader is referred to the report by Wigaeus et al. ${ }^{49}$

Acetone in the inspiratory air was analysed using the same gas chromatographic equipment as for styrene. The analysis of acetone in blood was performed using a headspace technique similar to that described elsewhere. ${ }^{50}$ Individual calibration curves were obtained by adding $2 \mu$ l of standard solutions of styrene and acetone in dimethylsulphoxide (DMSO) to $1 \mathrm{ml}$ of blood. A constant volume of 1 $\mathrm{ml}$ blood and $2 \mu \mathrm{l}$ of DMSO was used throughout the experiment. The concentration of acetone in subcutaneous adipose tissue was analysed by a gas chromatographic "purge-and-trap" method. .1 $^{1}$

Student's $t$ test for dependent observations was used for statistical analysis and a probability of 0.05 was taken as the criterion of significance.

\section{Results}

The total and relative uptakes of styrene were similar during the single and combined exposures, 4.4 (SD 0.4) and 4.2(SD 0.6) $\mathrm{mmol}$, and 68 (SD 5) and 67 (SD 5) per cent (table 1). The uptake of acetone was about $20 \mathrm{mmol}$, calculated from the amount supplied and assuming a relative uptake of $45 \% .^{50}$

The styrene concentration in the arterial blood (five subjects only because of the failure to introduce the catheter in one subject) increased during the first 75 minutes and then approached a steady state (fig 1). At the termination of exposure the mean concentration was 18 (SD 1) and 20 (SD 2) $\mu \mathrm{mol} / \mathrm{l}$ in the single and combined exposures, respectively; this difference was not statistically significant. The acetone concentration in blood increased linearly with time $(y=5.0 x+63.0 ; r=$
$0.99 ; \mathbf{n}=11)$ over the whole exposure period and reached 649 (SD 77) $\mu \mathrm{mol} / \mathrm{l}$ at the end of the exposure.

The total blood clearance, $\mathrm{Cl}_{4}$, of styrene (calculated from $\left.\mathrm{Cl}_{4}=\operatorname{dose} / \mathrm{AUC}_{\infty}\right)^{52}$ was 1.9 (SD 0.3) $1 / \mathrm{min}$ with the single exposure and 1.6 (SD 0.3 ) $1 /$ min with the combined exposure (table 2). This difference was not statistically significant.

The rate of elimination of styrene from the blood after exposure is shown in figs 1 and 2 and was considered to show a biphasic decay. Individual semilogarithmic plots of blood concentration versus time were treated by the method of residuals so as to resolve the curves into a linear terminal phase of slope $\beta$, and a linear initial phase of slope $\alpha^{53}$ (fig 2). The half life $\left(t_{1 / 2}\right)$ for the rapid distribution phase (0-5 min, $\alpha$ ) was 1.9 (SD 0.9) $\mathrm{min}$ and 1.1 (SD 0.1) min, and the $t_{1 / 2}$ of the elimination phase $(10-120$ $\min , \beta$ ) was 38.8 (SD 7.4) $\mathrm{min}$ and 35.0 (SD 10.2) min in the single and combined studies respectively (table 2). These differences were not statistically significant. A monoexponential decline (0-120 min) with a $t_{1 / 2}$ of 3.1 (SD 0.5) $h$ was observed for acetone in blood.

The volume of distribution, $\mathrm{V}_{\mathrm{d}} \beta$, of styrene (calculated from $\left.\mathrm{V}_{\mathrm{d}} \beta=\mathrm{t}_{1 / 2} \beta \times \mathrm{Cl}_{\mathrm{d}} / \ln 2\right)^{52}$ was 102 (SD 14) $l$ in the single exposure study and 84 (SD 39) $l$ in the combined study. This difference was not statistically significant.

The concentration of styrene in the subcutaneous adipose tissue 30 and 90 minutes after exposure was 62 (SD 17) and 53 (SD 17) $\mu \mathrm{mol} / \mathrm{kg}$ in the single exposure study and somewhat higher, 75 (SD 58) and 91 (SD 55) $\mu \mathrm{mol} / \mathrm{kg}$, in the combined study. The intraindividual variations were large, however, especially in the combined study. This may be 
Table 2 Calculated values of blood clearance $\left(\mathrm{Cl}_{t}\right)$, volume of distribution $\left(V_{d} \beta\right)$, and half lives $\left(t_{1 / 2}\right)$ of styrene, styrene glycol (SG) in blood and mandelic acid (MA), and phenylglyoxylic acid (PGA) in urine after two hours of inhalation exposure to about $2.81 \mathrm{mmol} / \mathrm{m}^{3}\left(293 \mathrm{mg} / \mathrm{m}^{3}\right)$ of styrene (St) and $2.89 \mathrm{mmol} / \mathrm{m}^{3}\left(301 \mathrm{mg} / \mathrm{m}^{3}\right)$ of styrene and $21.3 \mathrm{mmol} / \mathrm{m}^{3}\left(1240 \mathrm{mg} / \mathrm{m}^{3}\right)$ of acetone $(S t+A c)$ in combination during physical exercise with a work load of $50 \mathrm{~W}$. Mean values and standard errors of means are given

\begin{tabular}{lcl}
\hline & $S t$ & $S t+A c$ \\
\hline$C_{4}$ & $1.9 \pm 0.1 \mathrm{Vmin}$ & $1.6 \pm 0.1 \mathrm{lmin}$ \\
$\mathrm{V}_{\mathrm{d}} \beta$ & $102 \pm 6 \mathrm{l}$ & $84 \pm 18 \mathrm{l}$ \\
$\mathrm{t}_{1 / 2}$ styrene & $39 \pm 3 \mathrm{~min}$ & $35 \pm 4 \mathrm{~min}$ \\
$(10-120 \mathrm{~min})$ & $71 \pm 6 \mathrm{~min}$ & $66 \pm 2 \mathrm{~min}$ \\
$\mathrm{t}_{1 / 2} \mathrm{SG}$ & & \\
$(2 \cdot 5-120 \mathrm{~min})$ & $3.6 \pm 0.2 \mathrm{~h}$ & $4.0 \pm 0.5 \mathrm{~h}$ \\
$\mathrm{t}_{1 / 2} \mathrm{MA}$ & $\mathrm{MA}$ & $8.6 \pm 0.9 \mathrm{~h}$ \\
$\left(0^{2}-20 \mathrm{~h}\right)$ & $8.8 \pm 0.6 \mathrm{~h}$ & \\
$\mathrm{t}_{1 / 2}$ PGA & & \\
$\left(0^{2}-20 \mathrm{~h}\right)$ & & \\
\hline
\end{tabular}

because single samples only were analysed for their styrene content in the combined study whereas duplicate samples were taken and the mean values used in the single exposure study. The mean acetone concentration in the subcutaneous adipose tissue was 225 (SD 67) and 233 (SD 57) $\mu \mathrm{mol} / \mathrm{kg}$ at 30 and 90 minutes after exposure. The ratio of styrene in adipose tissue $\mathbf{3 0}$ minutes after exposure to that in arterial blood at the end of exposure was 3.5 (SD 0.5 ) in the single study and 3.9 (SD 3.7) in the combined study. The corresponding ratio for acetone was 0.35 (SD 0.08).

The arterial blood concentration of nonconjugated SG increased continuously during exposure and reached 3.1 (SD 1.2) $\mu \mathrm{mol} / \mathrm{l}$ in the single exposure study and $3.2(\mathrm{SD} 1.5) \mu \mathrm{mol} / \mathrm{l}$ in the combined study (fig 3 ). SO could not be detected in any of the samples in this experiment. After some analytical modifications ${ }^{49}$ a complementary study with four subjects was performed and 0.05 (SD $0.03) \mu \mathrm{mol} / 1$ of SO and 2.1 (SD 0.3) $\mu \mathrm{mol} / 1$ of SG were detected in venous blood collected 5-30 minutes after exposure.

A monoexponential decline of SG in blood was observed (fig 4). The mean $t_{1 / 2}(2 \cdot 5-120 \mathrm{~min})$ was 71 (SD 14) minutes in the single exposure study and 66 (SD 4) minutes in the combined study (table 2), a non-significant difference.

The cumulative urinary excretion of MA and PGA within a mean of 25 (SD 2) hours after exposure represented 51 (SD 8) per cent of the total uptake in the single exposure study. The corresponding value was 52 (SD 13) per cent within 24 (SD 4) hours in the combined study. The excretion rates of MA and PGA were considered to decline monoexponentially within 20 hours of exposure, and no difference between the two exposure condi-

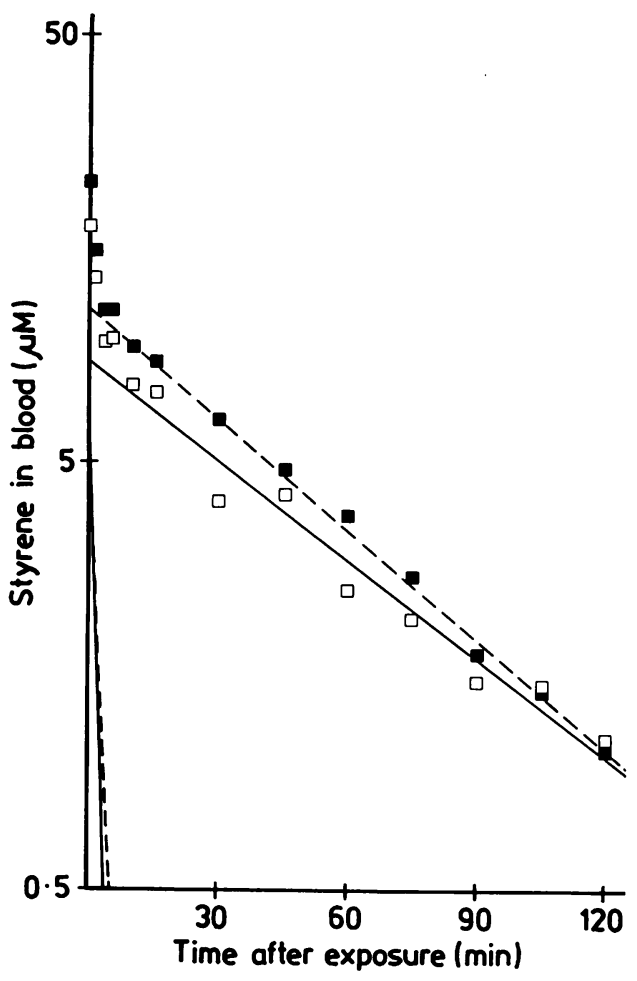

Fig 2 Semilogarithmic plot of concentration of styrene in arterial blood for five subjects after end of exposure to $2 \cdot 81$ $\mathrm{mmol} / \mathrm{m}^{3}\left(293 \mathrm{mg} / \mathrm{m}^{3}\right)$ of styrene ( $\square$ ) and to a combination of $2.89 \mathrm{mmol} / \mathrm{m}^{3}\left(301 \mathrm{mg} / \mathrm{m}^{3}\right)$ of styrene and $21.3 \mathrm{mmol} / \mathrm{m}^{3}$ $\left(1240 \mathrm{mg} / \mathrm{m}^{3}\right)$ of acetone ( $\square$ ) for two hours during physical exercise with a work load of $50 \mathrm{~W}$. Mean values $(n=5)$ are shown.

tions was observed. The $t_{1 / 2}$ for the elimination of MA was 3.6 (SD 0.5) hours in the single study and 4.0 (SD 1.2) hours in the combined study; for the elimination of PGA, the corresponding half lives were $8 \cdot 8($ SD $1 \cdot 5)$ and $8 \cdot 6($ SD $2 \cdot 1)$ hours (table 2).

\section{Discussion}

The calculated $\mathrm{Cl}_{\mathrm{t}}$ values for styrene of 1.9 and 1.6 $1 /$ min are of the same order as the total blood flow through the liver (about $1.6 \mathrm{l} / \mathrm{min}$ ) during rest or light physical exercise..$^{545}$ Styrene is mainly cleared by biotransformation. ${ }^{3940}$ Since the liver, with its high activity of styrene metabolising enzymes ${ }^{18-21}$ and its large mass, invariably contains more degradative enzymes than extrahepatic tissues the liver probably also plays a predominant part in vivo in the total clearance of styrene. Therefore the $\mathrm{Cl}_{\mathrm{t}}$ values obtained in this study can (apart from some 


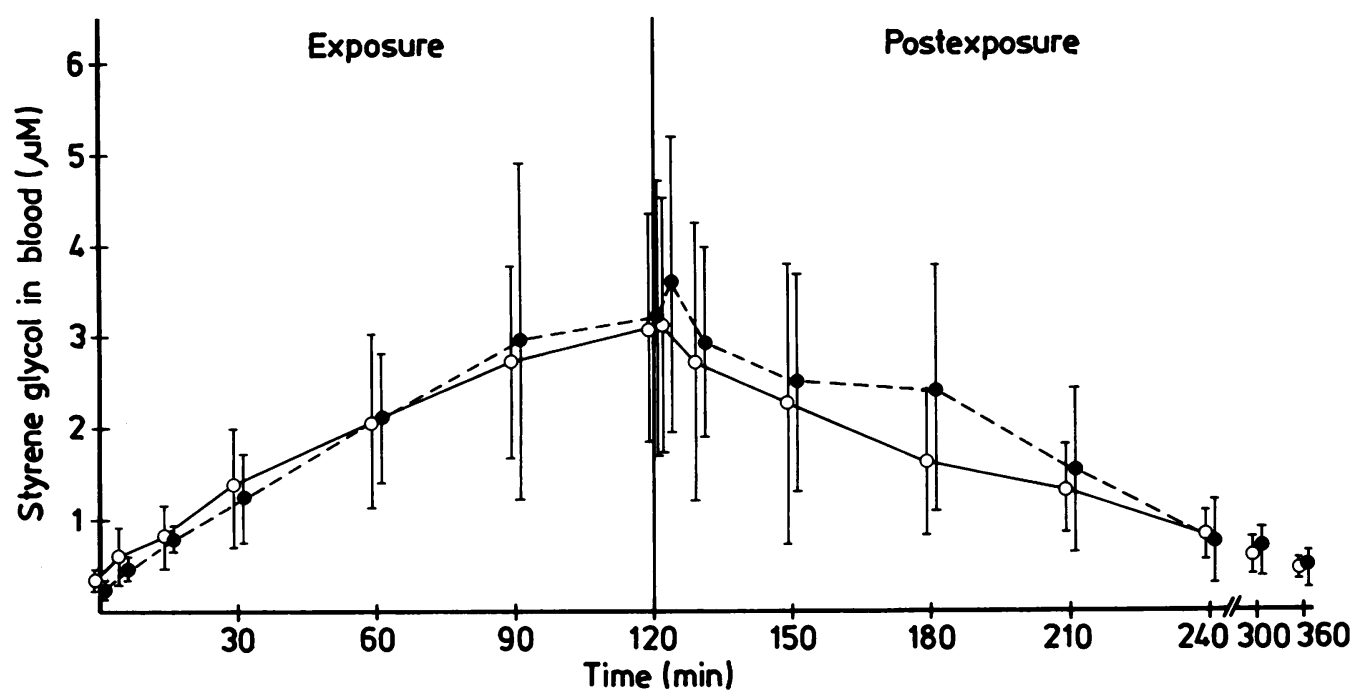

Fig 3 Concentration of styrene glycol in arterial blood for five subjects during and after exposure to $2 \cdot 81$ $\mathrm{mmol} / \mathrm{m}^{3}\left(293 \mathrm{mg} / \mathrm{m}^{3}\right)$ of styrene (O) and to a combination of $2.89 \mathrm{mmol} / \mathrm{m}^{3}\left(301 \mathrm{mg} / \mathrm{m}^{3}\right)$ of styrene and 21.3 $\mathrm{mmol} / \mathrm{m}^{3}\left(1240 \mathrm{mg} / \mathrm{m}^{3}\right)$ of acetone (O) for two hours during physical exercise with a work load of $50 \mathrm{~W}$. The two last values represent venous blood. Mean values $(n=5)$ and standard deviations are shown.

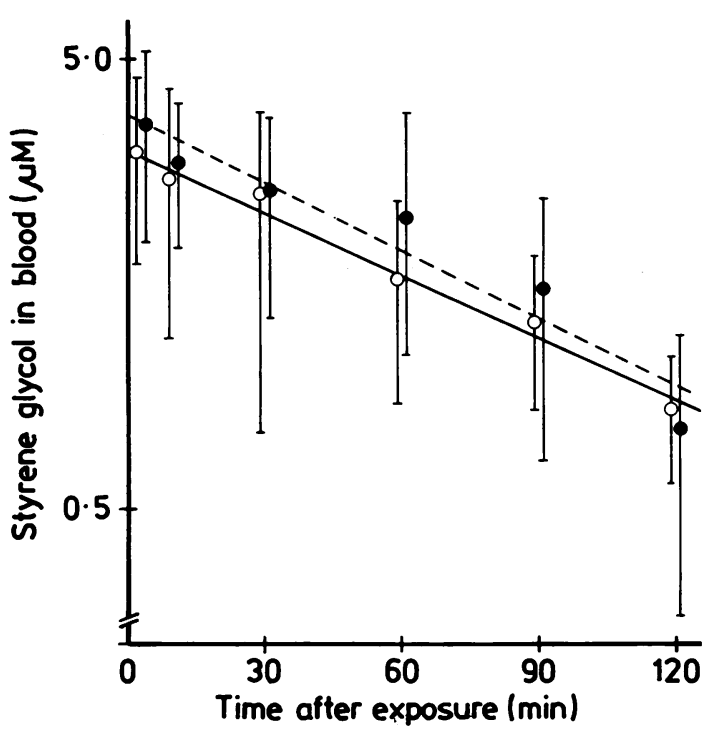

Fig 4 Semilogarithmic plot of concentration of styrene glycol in arterial blood after end of exposure to $2 \cdot 81$ $\mathrm{mmol} / \mathrm{m}^{3}\left(293 \mathrm{mg} / \mathrm{m}^{3}\right)$ of styrene (O) and to a combination of $2.89 \mathrm{mmol} / \mathrm{m}^{3}\left(301 \mathrm{mg} / \mathrm{m}^{3}\right)$ of styrene and $21.3 \mathrm{mmol} / \mathrm{m}^{3}$ $\left(1240 \mathrm{mg} / \mathrm{m}^{3}\right)$ of acetone (O) for two hours during physical exercise with a work load of $50 \mathrm{~W}$.

continued accumulation in adipose tissue) be mainly ascribed to hepatic clearance with a minor contribu- tion only from metabolism in extrahepatic tissues. Thus at low exposures styrene seems to be effectively extracted from the blood perfusing the liver-that is, the hepatic extraction ratio $\left(E_{h}\right) \rightarrow 1$. The claim that in rats styrene at low levels is metabolised in a high affinity perfusion limited pathway s6 seems to be valid also in man.

With higher exposures the elimination kinetics of styrene from the blood have been found to be dose dependent, indicating a saturation of the rate limiting step. ${ }^{.5-59}$ The saturating exposure level of styrene vapour was estimated to be between 200 and $600 \mathrm{ppm}\left(8.2\right.$ and $\left.24.5 \mathrm{mmol} / \mathrm{m}^{3}\right)$ in rats. ${ }^{58}$ Dose dependent urinary excretion of MA and PGA after styrene administration has also been shown. ${ }^{60}$ There are indications in published reports of dose dependent urinary excretion of MA and PGA in occupationally exposed workers also. ${ }^{6162}$ Guillemin and Bauer, however, found that the rates of elimination of MA and PGA during short term (4-8 h) experimental exposure to $50-200 \mathrm{ppm}\left(2 \cdot 0-8 \cdot 2 \mathrm{mmol} / \mathrm{m}^{3}\right)$ were not dose dependent. ${ }^{40}$ The decreased half life of MA excretion shown in workers exposed to higher concentrations indicates a possible enzyme induction by styrene itself resulting in an increased rate of breakdown. A decreased styrene accumulation in rat tissues after prolonged exposure also suggests metabolic adaptation. ${ }^{\circ 3}$ Stimulating agents are not able to enhance the metabolic rate of high affinity chemicals occurring at low concentrations 
(below $\mathrm{Km}$, app), however, implying a perfusion limited metabolic clearance. ${ }^{56}$ The extrahepatic metabolism of styrene is not necessarily perfusion limited, however, even at low concentrations and the activities of styrene mono-oxygenase and epoxide hydratase in the extrahepatic tissues of many species are lower, and therefore easier to saturate, than those in the liver. ${ }^{18-21}$ Consequently the stimulation of extrahepatic drug metabolising enzymes might increase the rate of clearance of styrene. The lung may be of particular importance since it receives all of the cardiac output ${ }^{64}$; changes in tissue perfusion might also modify tissue extraction and hence clearance.

The $t_{1 / 2}$ of styrene in blood is dependent on $\mathrm{Cl}_{4}$ and $\mathrm{V}_{\mathrm{d}}:\left(\mathrm{t}_{1 / 2}=\ln 2 \times \mathrm{V}_{\mathrm{d}} / \mathrm{Cl}_{\mathrm{t}}\right)$. $^{52}$ In rats $\mathrm{V}_{\mathrm{d}}$ of styrene is independent of the dose $(12 \cdot 5-90 \cdot 3 \mu \mathrm{mol} / \mathrm{kg})$ wheras the $\mathrm{Cl}_{4}$ is dose dependent, giving a longer $\mathrm{t}_{1 / 2}$ with increasing doses. ${ }^{58}$ The calculated mean values of $\mathrm{V}_{\mathrm{d}}, \mathrm{Cl}_{\mathrm{t}}$, and $\mathrm{t}_{1 / 2}$ were all somewhat lower in the combined study compared with the single exposure study (table 2).

In this study the solvent concentrations, work load, or exposure time, or a combination of these, were not adequate enough to cause a noticeable interference of $\mathrm{Cl}_{\mathrm{t}}$. The minimal blood acetone concentration capable of inducing carbon tetrachloride hepatotoxicity in rats has been estimated to be about $5 \mathrm{mmol} / \mathrm{l}^{\mathrm{B}}$ - that is, only about eight times higher than the blood concentration obtained in this study. Pretreatment of rats with high doses of acetone ( 60 $\mathrm{mmol} / \mathrm{kg}$ intraperitoneally) has been shown to affect the hepatic microsomal drug metabolising activity within 15 minutes..$^{45}$ At lower doses $(2.2 \mathrm{mmol} / \mathrm{kg}$ intraperitoneally) acetone did not modify the total urinary excretion of mandelic and phenylglyoxylic acid after an equimolar dose of styrene as compared with the excretion after administration of styrene alone. ${ }^{27}$ The possible modification of the formation of SO from styrene and the subsequent hydration to SG, however, is of greater toxicological importance.

No modification of either the formation or the oxidation, or both, of SG or the excretion of MA and PGA was seen in the combined exposure. An increased concentration of SG in blood and a delayed excretion of MA in the urine have been noted after the co-administration of ethanol (p.o) and styrene, as compared with styrene inhalation alone. ${ }^{25}$

The present study did not show any significant interactions of acetone on the uptake, distribution, metabolism, or elimination, or a combination of these, of styrene during acute co-exposure to acetone at the recommended Swedish short term exposure limit concentrations and light physical work.
We are very grateful to Professor I Åstrand for encouraging and valuable discussions. We are also grateful to Ms E Gullstrand, Ms E Lundgren, Ms E-M Nydahl, Ms C Uggla, and Ms $\mathrm{K}$ Wiberg for their skilfull technical help, and Ms M-B Cedervall for her patient typing of this manuscript.

\section{References}

Tossavainen A. Styrene use and occupational exposure in the plastics industry. Scand J Work Environ Health 1978;4:7-13.

${ }^{2}$ Kjellberg A, Wigaeus E, Åstrand I, Engström J, Ljungquist E. Long-term effects of exposure to styrene in a polyester plant. Arbete och Hälsa 1979;18:1-25. (Summary in English.)

${ }^{3}$ Cornish HH, Adefuin J. Potentiation of carbon tetrachloride toxicity by aliphatic alcohols. Arch Environ Health 1967; 14:447-9.

${ }^{4}$ Côté MG, Traiger GJ, Plaa GL. Effect of isopropanol-induced potentiation of carbon tetrachloride on rat hepatic ultrastructure. Toxicol Appl Pharmacol 1974;30:14-25.

s Traiger GJ, Plaa GL. Chlorinated hydrocarbon toxicity. Potentiation by isopropyl alcohol and acetone. Arch Environ Health 1974;28:276-8.

- Hewitt WR, Miyajima H, Côté MG, Plaa GL. Acute alteration of chloroform-induced hepato- and nephrotoxicity by $n$-hexane, methyl n-butyl ketone, and 2, 5-hexanedione. Toxicol Appl Pharmacol 1980;53:230-48.

${ }^{7}$ MacDonald JR, Gandolfi AJ, Sipes IG. Acetone potentiation of 1,1,2-trichloroethane hepatotoxicity. Toxicol Lett 1982; 13:57-69.

${ }^{8}$ Plaa GL, Hewitt WR, du Souich P, Caillé G, Lock S. Isopropanol and acetone potentiation of carbon tetrachloride-induced hepatotoxicity: single versus repetitive pretreatments in rats. $J$ Toxicol Environ Health 1982;9:235-50.

${ }^{9}$ Folland DS, Schaffner W, Grinn HE, Crofford OB, McMurray DR. Carbon tetrachloride toxicity potentiated by isopropyl alcohol. Investigation of an industrial outbreak. JAMA 1976; 236: 1853-6.

${ }^{10}$ Sipes IG, Stripp B, Krishna G, Maling HM, Gillette JR. Enhanced hepatic microsomal activity by pretreatment of rats with acetone or isopropanol. Proc Soc Exp Biol Med 1973; 142:237-40.

" MacDonald JR, Gandolfi AJ, Sipes IG. Covalent binding of ${ }^{14} \mathrm{C}-1,1,2$-trichloroethane to hepatic proteins following acetone pretreatment. Drug Chem Toxicol 1982;5:233-47.

12 Traiger GJ, Plaa GL. Relationship of alcohol metabolism to the potentiation of $\mathrm{CCl}_{4}$ hepatotoxicity induced by aliphatic alcohols. J Pharmacol Exp Ther 1972; 183:481-8.

${ }^{13}$ Glende EA Jr, Recknagel RO. Biochemical basis for the in vitro pro-oxidant action of carbon tetrachloride. Exp Mol Pathol 1969;11:172-85.

${ }_{14}$ Plaa GL, Traiger GJ. Mechanism of potentiation of $\mathrm{CCl}_{4}$-induced hepatotoxicity. Pharmacology and the future of man. Vol 2. Proceedings of the 5th International Congress of Pharmacology, San Francisco, 1972. Basel: Karger, 1973:100-13.

is Traiger GJ, Plaa GL. Effect of aminotriazole on isopropanoland acetone-induced potentiation of $\mathrm{CCl}_{4}$ hepatotoxicity. Can J Physiol Pharmacol 1973;5:291-6.

${ }^{16}$ Maling HM, Stripp B, Sipes IG, Highman B, Saul W, Williams MA. Enhanced hepatotoxicity of carbon tetrachloride, thioacetamide, and dimethylnitrosamine by pretreatment of rats with ethanol and some comparisons with potentiation by isopropanol. Toxicol Appl Pharmacol 1975;33:291-308.

${ }^{17}$ Sipes IG, Slocumb ML, Holtzman G. Stimulation of microsomal dimethylnitrosamine- $\mathrm{N}$-demethylase by pretreatment of mice with acetone. Chem Biol Interactions 1978;21:155-66. 
${ }^{18}$ Ryan AJ, James MO, Ben-Zvi Z, Law FCP, Bend JR. Hepatic and extrahepatic metabolism of ${ }^{14} \mathrm{C}$-styrene oxide. Environ Health Perspect 1976;17:135-44.

19 Salmona M, Pachecka J, Cantoni L, Belvedere G, Mussini E, Garattini S. Microsomal styrene monooxygenase and styrene epoxide hydrase activities in rats. Xenobiotica 1976;6:585-91.

${ }^{20}$ Cantoni L, Salmona M, Facchinetti T, Pantarotto C, Belvedere G. Hepatic and extrahepatic formation and hydration of styrene oxide in vitro in animals of different species and sex. Toxicol Lett 1978;2:179-86.

${ }^{21}$ Pantarotto C, Salmona M, Szczawinska K, Bidoli F. Gas chromatographic-mass spectrometric studies on styrene toxicity. In: A'lbaiges I, ed. Analytical techniques in environmental chemistry. Oxford: Pergamon Press, 1980:245-79.

${ }^{22}$ Parkki MG, Marniemi J, Vainio H. Action of styrene and its metabolites styrene oxide and styrene glycol on activities of xenobiotic biotransformation enzymes in rat liver in vivo. Toxicol Appl Pharmacol 1976;38:59-70.

${ }^{23}$ Sandell J, Parkki MG, Marniemi J, Aitio A. Effects of inhalation and cutaneous exposure to styrene on drug metabolizing enzymes in the rat. Res Commun Chem Pathol Pharmacol 1978; 19:109-18.

${ }^{24}$ Ohtsuji $\mathrm{H}$, Ikeda $\mathrm{M}$. The metabolism of styrene in the rat and the stimulatory effect of phenobarbital. Toxicol Appl Pharmacol 1971;18:321-8.

${ }^{25}$ Wilson HK, Robertson SM, Waldron HA, Gompertz D. Effect of alcohol on the kinetics of mandelic acid excretion in volunteers exposed to styrene vapour. Br J Ind Med 1983;40:75-80.

${ }^{26}$ Ikeda $\mathrm{M}$, Ohtsuji $\mathrm{H}$, Imamura $\mathrm{T}$. In vivo suppression of benzene and styrene oxidation by co-administered toluene in rats and effect of phenobarbital. Xenobiotica 1972;2:101-6.

${ }^{27}$ Ikeda M, Hirayama T. Possible metabolic interaction of styrene with organic solvents. Scand J Work Environ Health $1978 ; 4: 41-6$.

${ }^{28}$ Leibman KC, Ortiz E. Styrene epoxide-an intermediate in microsomal oxidation of styrene to its glycol. Pharmacologist 1968;10:203.

${ }^{29}$ Leibman KC, Ortiz E. Epoxide intermediates in microsomal oxidation of olefins to glycols. J Pharmacol Exp Ther 1970: 173:242-6.

${ }^{30}$ Loprieno N, Abbondandolo A, Baralf R, et al. Mutagenicity of industrial compounds: styrene and its possible metabolite styrene oxide. Mutat Res 1976; 40:317-24.

${ }^{31}$ Milvy P, Garro AJ. Mutagenic activity of styrene oxide (1,2epoxyethylbenzene), a presumed styrene metabolite. Mutat Res 1976;40:15-8.

${ }^{32}$ Vainio H, Pääkkönen R, Rönnholm K, Raunio V, Pelkonen O. A study on the mutagenic activity of styrene and styrene oxide. Scand J Work Environ Health 1976;3:147-51.

${ }^{33}$ de Meester C, Poncelet F, Roberfroid M, Rondelet J, Mercier M. Mutagenicity of styrene and styrene oxide. Mutat Res 1977;56:147-52.

${ }^{34}$ Stoltz DR, Withey RJ. Mutagenicity testing of styrene and styrene epoxide in salmonella typhimurium. Bull Environ Contam Toxicol 1977;17:739-42.

${ }^{35}$ Busk L. Mutagenic effects of styrene and styrene oxide. Mutat Res 1979;67:201-8.

${ }^{36}$ Marniemi J, Suolinna EM, Kaartinen N, Vainio H. Covalent binding of styrene oxide to rat liver macromolecules in vivo and in vitro. In: Ullrich V, Roots I, Hildebrand A, Estabrook RW, Conney A, eds. Microsomes and drug oxidations. Proceedings of the 3rd International Symposium Berlin, 1976. Oxford: Pergamon Press, 1977:698-703.

${ }^{37}$ Oesch F, Jerina DM, Daly J. A radiometric assay for hepatic epoxide hydrase activity with $\left(7-{ }^{3} \mathrm{H}\right)$ styrene oxide. Biochim Biophys Acta 1971;227:685-91.

${ }^{38}$ Oesch F, Thoenen H. Epoxide hydrase in human liver biopsy specimens: assay and properties. Biochem Pharmacol 1974;23:1307-17.

${ }^{39}$ Caperos JR, Humbert B, Droz PO. Styrene exposure, II.
Percentage studies of absorption, excretion, and metabolism by human subjects. Int Arch Occup Environ Health 1979; 42:223-30. (Summary in English.)

${ }^{40}$ Guillemin MP, Bauer D. Human exposure to styrene, III. Elimination kinetics of urinary mandelic and phenylglyoxylic acids after single experimental exposure. Int Arch Occup Environ Health 1979;44:249-63.

${ }^{41}$ Anders MW. Acetone enhancement of microsomal aniline parahydroxylase activity. Arch Biochem Biophys 1968;126:26975.

42 Vainio H, Hänninen $\mathrm{O}$. Enhancement of aniline p-hydroxylation by acetone in rat liver microsomes. Xenobiotica 1972;2:259. 67.

${ }^{43}$ Cinti DL. Agents activating the liver microsomal mixed function oxidase system. Pharm Ther 1978;2:727-49.

${ }^{4}$ Moldéus P, Gergely V. Effect of acetone on the activation of acetaminophen. Toxicol Appl Pharmacol 1980;53:8-13.

${ }^{45}$ Clark H, Powis G. Effect of acetone administered in vivo upon hepatic microsomal drug metabolizing activity in the rat. Biochem Pharmacol 1974;23:1015-9.

${ }^{46}$ Kitada M, Kamataki T, Kitagawa $\mathrm{H}$. Enhancement in vivo of drug oxidations following administration of benzphetamine, acetone, metyrapone and dimethylsulfoxide. Jpn J Pharmacol 1978; 28:213-21.

${ }^{47}$ Vainio H, Zitting A. Interaction of styrene and acetone with drug biotransformation enzymes in rat liver. Scand J Work Environ Health 1978;4:47-52.

${ }^{48}$ Vainio H, Järvisalo J, Taskinen E. Adaptive changes caused by intermittent styrene inhalation on xenobiotic biotransformation. Toxicol Appl Pharmacol 1979;49:7-14.

49 Wigaeus E, Löf A, Bjurström R, Byfält Nordqvist M. Exposure to styrene. Uptake, distribution, metabolism and elimination in man. Scand J Work Environ Health 1983;9:479-88.

${ }^{\text {so }}$ Wigaeus E, Holm S, Åstrand I. Exposure to acetone. Uptake and elimination in man. Scand J Work Environ Health 1981;7:84-94.

${ }^{51}$ Holm S, Lundgren E. A purge-and-trap method for the analysis of acetone in biological tissues. Anal Biochem 1984; 136: $157-60$.

s2 Rowland M, Tozer TN. Clinical pharmacokinetics: concepts and application. Philadelphia: Lea \& Febiger, 1980.

${ }^{53}$ Mayersohn M, Gibaldi M. Mathematical methods in pharmacokinetics. American Journal of Pharmaceutical Education 1971;35:19-28.

54 Rowell LB. Human cardiovascular adjustments to exercise and thermal stress. Physiol Rev 1974;54:75-159.

ss Åstrand I. Effect of physical exercise on uptake, distribution and elimination of vapors in man. In: Fiserova-Bergerova E, ed. Modeling of inhalation exposure to vapors: uptake, distribution and elimination. Vol 2. Boca Raton, Florida: CRC Press Inc, 1983:107-30.

${ }^{56}$ Andersen ME. Saturable metabolism and its relationship to toxicity. CRC Crit Rev Toxicol 1981;9:105-50.

57 Withey JR, Collins PG. Pharmacokinetics and distribution of styrene monomer in rats after intravenous administration. $J$ Toxicol Environ Health 1977;3:1011-20.

${ }^{58}$ Ramsey JC, Young JD. Pharmacokinetics of inhaled styrene in rats and humans. Scand J Work Environ Health 1978;4:84-91.

${ }^{59}$ Withey JR. The toxicology of styrene monomer and its pharmacokinetics and distribution in the rat. Scand J Work Environ Health 1978;4:31-40.

${ }^{\infty}$ Ikeda M, Imamura T. Evaluation of hippuric, phenylglyoxylic and mandelic acids in urine as indices of styrene exposure. Internationale Archiv für Arbeitsmedizin 1974;32:93-101.

${ }^{61}$ Götell P, Axelson O, Lindelöf B. Field studies on human styrene exposure. Work Environ Health 1972;9:76-83.

${ }^{62}$ Engström K, Härkönen H, Kalliokoski P, Rantanen J. Urinary mandelic acid concentration after occupational exposure to styrene and its use as a biological exposure test. Scand J Work Environ Health 1976;2:21-6. 
${ }^{63}$ Savolainen H, Pfäffli P. Effects of chronic styrene inhalation on rat brain protein metabolism. Acta Neuropath (Berl) 1977; 40:237-41.
${ }^{64}$ Roth RA, Wiersma DA. Role of the lung in total body clearance of circulating drugs. Clin Pharmacokinet 1979;4:355-67.

\section{The August 1984 issue}

\section{THE AUGUST 1984 ISSUE CONTAINS THE FOLLOWING PAPERS}

Effect of the air hammer on the hands of stonecutters. The limestone quarries of Bedford, Indiana, revisited W TAYLOR, D WASSERMAN, V BEHRENS, D REYNOLDS, AND S SAMUELOFF

Chest pain in rubber chemical workers exposed to carbon disulphide and methaemoglobin formers $\mathrm{L}$ CHRISTINE OLIVER AND R P WEBER

Exposure to solvents and outcome of pregnancy in university laboratory employees GÖSTA AXELSSON, C LÜTZ, AND R RYLANDER

High accuracy (stable isotope dilution) measurements of lead in serum and cerebrospinal fluid W I MANTON AND J D COOK

Diesel exposure and mortality among railway workers: results of a pilot study M B SCHENKER, T SMITH, A MUÑOZ, SUSAN WOSKIE, AND F E SPEIZER

Epidemiological study of the lung function of workers at a factory manufacturing polyvinylchloride $M$ H LLOYD, S GAULD, L COPLAND, AND C A SOUTAR

Classification of progressive massive fibrosis of coalminers by type of radiographic appearance CA SOUTAR AND H P R COLLINS

Exposure to cotton dust in an experimental cardroom P HAGLIND AND R RYLANDER

Respiratory symptoms and lung function in a group of solderers D COURTNEY AND J D MERRETT

Occupational lead neurotoxicity: a behavioural and electrophysiological evaluation. Study design and year one results $E$ L BAKER, $R$ G FELDMAN, ROBERTA A WHITE, J P HARLEY, C A NILES, G E DINSE, AND CATHERINE $S$ BERKEY

Ethylene thiourea: thyroid function in two groups of exposed workers DONALDA M SMITH

Telangiectasia in aluminium workers: a follow up G THERIAULT, SUZANNE GINGRAS, AND SIMONE PROVENCHER
Radiographic assessment of pleuropulmonary disease in asbestos workers: posteroanterior, four view films, and computed tomograms of the thorax $R$ BEGIN, M BOCTOR, D BERGERON, A CANTIN, Y BERTHIAUME, S PÉLOQUIN, G BISSON, AND G LAMOUREUX

Radiographic changes in a group of chrysotile miners and millers exposed to low asbestos dust concentrations SYLVAINE CORDIER, G THERIAULT, AND SIMONE PROVENCHER

In vitro biodegradation of chrysotile fibres by alveolar macrophages and mesothelial cells in culture: comparison with a $\mathrm{pH}$ effect $\mathrm{M}$ C JAURAND, A GAUDICHET, $S$ HALPERN, AND J BIGNON

Binding of environmental carcinogens to asbestos and mineral fibres G HARVEY, M PAGE, AND L DUMAS

A three-frequency audiogram for use in industry A SINCLAIR AND T A SMITH

Comparison of the in vivo and in vitro effects of lead on the $\mathrm{pH}$-activity relationship of human erythrocytic $\delta$-aminolaevulinic acid dehydratase J P FARANT AND D C WIGFIELD

Relation between the iodine azide test and the TTCA test for exposure to carbon disulphide J ROSIER, G BILLEMONT, C VAN PETEGHEM, M VANHOORNE, R GROSJEAN, AND E VAN DE WALLE

Notes and miscellanea:

HLA Antigens of the A and B locus in relation to the development of silicosis

Toxocaral antibodies in personnel occupationally concerned with dogs

Methylene chloride burns

Information section

Copies are still available and may be obtained from the PUBLISHING MANAGER, BRITISH MEDICAL ASSOCIATION; TAVISTOCK SQAURE, LONDON WC1H 9JR, price $£ 4 \cdot 25$ (USA \$9.20), including postage. 